(2)

\title{
Modeling the impact of growth and leptin deficits on the neuronal regulation of blood pressure
}

\author{
Baiba Steinbrekera and Robert Roghair
}

Stead Family Department of Pediatrics, Carver College of Medicine, University of lowa, lowa City, lowa, USA

Correspondence should be addressed to R Roghair

Email

robert-roghair@uiowa.edu

\begin{abstract}
The risk of hypertension is increased by intrauterine growth restriction (IUGR) and preterm birth. In the search for modifiable etiologies for this life-threatening cardiovascular morbidity, a number of pathways have been investigated, including excessive glucocorticoid exposure, nutritional deficiency and aberration in sex hormone levels. As a neurotrophic hormone that is intimately involved in the cardiovascular regulation and whose levels are influenced by glucocorticoids, nutritional status and sex hormones, leptin has emerged as a putative etiologic and thus a therapeutic agent. As a product of maternal and late fetal adipocytes and the placenta, circulating leptin typically surges late in gestation and declines after delivery until the infant consumes sufficient leptin-containing breast milk or accrues sufficient leptin-secreting adipose tissue to reestablish the circulating levels. The leptin deficiency seen in IUGR infants is a multifactorial manifestation of placental insufficiency, exaggerated glucocorticoid exposure and fetal adipose deficit. The preterm infant suffers from the same cascade of events, including separation from the placenta, antenatal steroid exposure and persistently underdeveloped adipose depots. Preterm infants remain leptin deficient beyond term gestation, rendering them susceptible to neurodevelopmental impairment and subsequent cardiovascular dysregulation. This pathologic pathway is efficiently modeled by placing neonatal mice into atypically large litters, thereby recapitulating the perinatal growth restriction-adult hypertension phenotype. In this model, neonatal leptin supplementation restores the physiologic leptin surge, attenuates the leptintriggered sympathetic activation in adulthood and prevents leptin- or stress-evoked hypertension. Further pathway interrogation and clinical translation are needed to fully test the therapeutic potential of perinatal leptin supplementation.
\end{abstract}

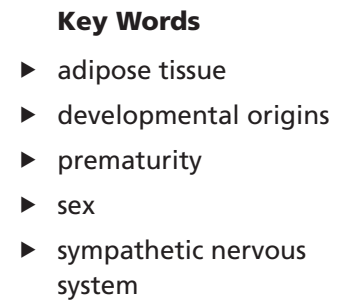

Journal of Endocrinology (2016) 231, R47-R60

\section{Introduction}

Leptin is a pleiotropic hormone with early neurotrophic effects on the hypothalamus (Bouret et al. 2004, Pinto et al. 2004). Later in life, leptin acts as a homeostatic agent by balancing appetite and sympathetic activity with energy stores such that increased adiposity increases circulating leptin levels, reducing appetite and increasing sympathetic tone. In addition to promoting energy expenditure, this sympatheticactivation increases blood pressure (Rahmouni \& Morgan 2007). According to the developmental origins of adult disease construct, physiologic challenges early in 
life can skew the developmental processes during critical windows of susceptibility. This potentially can leave longstanding pathologic repercussions if the altered regulatory processes are rigidly established. This review presents the evidence of an attenuated late gestation leptin surge in intrauterine growth-restricted (IUGR) or preterm infants. With IUGR and prematurity each affecting at least ten percent of all pregnancies, this perinatal leptin deficiency influences nearly a quarter of all infants (WHO 1995, Beck et al. 2010), supporting the development of translational models. We review the clinical and preclinical data leading to murine models designed to test the hypothesis that neonatal leptin deficiency leads to permanent alterations in hypothalamic leptin signaling, predisposing to leptinevoked hypertension in adulthood (Fig. 1).

\section{Perinatal growth restriction, prematurity and adult hypertension}

\section{Clinical investigations}

Intrauterine growth restriction is a strong, independent risk factor for adult cardiovascular disease. International investigations over the past three decades have reaffirmed the landmark epidemiological observations of Barker and coworkers (1989). In those seminal studies, an inverse relationship was noted between birth weight and ischemic heart disease. Although dyslipidemia and obesity often coexist, hypertension remains a modifiable risk factor for life-threatening heart disease. Subsequent studies have thus focused on the association between IUGR and adult hypertension.
Consistent with the earlier investigations, a number of studies over the following decades demonstrated an inverse correlation between birth weight and adult blood pressure (Curhan et al. 1999, Eriksson et al. 2007). In a large twin cohort study, Bergvall and coworkers (2007) found decreased birth weight associated with increased risk of hypertension independent of genetic factors, shared familial environment and adult body mass index. Although relatively few human studies have been powered for sex-specific effects, the available data are consistent with sex differences in the developmental origins of hypertension (Intapad et al. 2014). Jones and coworkers (2008) and Miles and coworkers (2011) have each shown that former IUGR men but not women have increased baseline blood pressure that is exacerbated by psychological stress, and this sexual dimorphism has been a consistent theme in preclinical animal models (Intapad et al. 2014).

Clinical investigations into the potential etiology of IUGR-associated hypertension have consistently demonstrated increased sympathetic tone in formerly or persistently growth-restricted adults, including heightened peroneal nerve traffic, urinary catecholamine excretion and stress-evoked cardiovascular alterations (Boguszewski et al. 2004, Johansson et al. 2007, Jones et al. 2008). Intriguingly, the stress hypertension seen in IUGR infants correlates with a lack of salivary cortisol response to painful procedures, suggesting programmed alterations in hypothalamic function (Schäffer et al. 2009). This contrasts with the increased cortisol response typically seen in adults with stress-evoked hypertension (Grant et al. 2009). Studies on autonomic blood pressure regulation in adults generally
A

Physiologic Leptin Surge
$\begin{aligned} & \text { Human: Gestational Weeks 32-40 } \\ & \text { Murine: Postnatal Days 4-14 }\end{aligned}$
Hypothalamic Development
$\begin{aligned} & \text { Appetite Regulation } \\ & \text { Sympathetic Balance }\end{aligned}$
Adult Homeostasis

B
Attenuated Leptin Surge
Human: IUGR or Prematurity
Murine: Neonatal Growth Restriction
Both: Glucocorticoid Exposure
Abnormal Hypothalamic Development
Increased Central Adiposity
Sympathetic Over-Activation
Adult Leptin-Evoked Hypertension

\section{Figure 1}

The importance of the perinatal leptin surge as a stimulus for hypothalamic development. (A) During normal human pregnancy, fetal leptin levels rapidly increase from gestational week 32 to delivery. Mice have a relative delay in adipogenesis, and an analogous increase in leptin does not occur until postnatal days 4-14. In both species, the physiologic increase in perinatal leptin is critical for normal hypothalamic development. In adulthood, cardiometabolic homeostasis is facilitated by well-tuned appetite regulation and sympathetic tone. (B) Perinatal leptin deficiency can occur after intrauterine growth restriction (IUGR) or prematurity in humans, neonatal growth restriction in mice or exaggerated perinatal glucocorticoid exposure in both species. The attenuated leptin surge increases the risk of hypothalamic hypoplasia and dysregulation with the potential for hypersensitivity to leptin-triggered sympathetic activation in the presence of selective resistance to leptin-mediated anorexia. Individuals with obesity-related hyperleptinemia in the presence of heightened leptin-mediated sympathetic activation are at dramatically increased risk of adult hypertension. 
do not report birth weight or gestational age at delivery. Longitudinal assessment of premature or growth-restricted populations will be necessary to identify the temporal relationship between sympathoadrenal activation and the development of hypertension.

The impact of IUGR on adult blood pressure is significantly influenced by the rate of postnatal growth. Central adiposity is seen in a subpopulation of growthrestricted individuals who otherwise remain smaller than their normal birth weight peers (Hack et al. 2003, Crume et al. 2014). Neonatal growth acceleration increases the risk of adult obesity and hypertension (Ben-Shlomo et al. 2008), whereas continued growth restriction throughout infancy increases the risk of hypertension and ischemic heart disease more than that seen after IUGR alone (Barker et al. 1989, Eriksson et al. 2007). More so than term infants, premature infants are at substantial risk for neonatal growth restriction, with $90 \%$ of preterm infants developing postnatal weights below the 10th percentile by the time of hospital discharge (Dusick et al. 2003). Extremely low birth weight children remain smaller than their peers in regard of height and weight at age 8 years, and by 14 years, boys catch up, but girls continue to remain smaller (Hack et al. 2014). In part related to this near universal prematurity-associated neonatal growth restriction, preterm birth trumps IUGR as a risk factor for hypertension (Johansson et al. 2005).

As seen in IUGR infants, preterm infants have additional cardiovascular risk factors consistent with sympathetic over-activation, including increased catecholamine excretion, increased resting heart rates, and exaggerated pressor responses to psychological stress (Ward et al. 2004, Johansson et al. 2007, Jones et al. 2007, Pyhälä et al. 2009). Up to $70 \%$ of preterm infants demonstrate elevated systolic blood pressure as early as 1 year of age, and hypertension remains a significant health concern into adulthood, especially in the presence of adult obesity (Johansson et al. 2005, Pyhälä et al. 2009, Dagle et al. 2011, Duncan et al. 2011, Sipola-Leppänen et al. 2015). The fact that prematurityrelated hypertension persists into adulthood puts significant afterload on the heart for decades (de Jong et al. 2012, Kerkhof et al. 2012), potentially contributing to the abnormal cardiac dimensions seen even in infancy (Lewandowski et al. 2013, Sehgal et al. 2013). Unfortunately, this hypertensive phenotype is present among infants born as late as during 37-week gestation (Gunay et al. 2014), and unlike the sexual dimorphism seen in IUGR infants, both preterm boys and girls appear to be at a heightened risk of adult hypertension (Bonamy et al. 2012). Notably, the same neurodevelopmental consequences that follow preterm delivery have been increasingly reported in IUGR infants, including reduced brain volumes and impaired neuronal connectivity (Miller et al. 2016), suggesting a potential common etiology linking neurodevelopment and the neuronal regulation of blood pressure.

\section{Murine model}

Animal models have been indispensable in elucidating the physiologic and cellular processes that are altered by perinatal growth restriction. Interspecies differences are important considerations in identifying appropriate preclinical models to test critical hypotheses. We continue to collaborate with others in the pursuit of answers in sheep, rats and mice with notable sex-specific phenotypes observed (Roghair \& Aldape 2007, Roghair et al. 2009, Katkhuda et al. 2012). Important investigations in rats have already shown that late-gestation uterine artery ligation elicits intrauterine growth restriction, increased sympathetic tone and postmenopausal hypertension that can be normalized by estrogen replacement or bilateral renal denervation (Ojeda et al. 2007, Intapad et al. 2013). Likewise, maternal malnutrition-induced IUGR programs sympathetic nerve overactivity in response to physical stress (Mizuno et al. 2013). Interestingly, it has been shown that the effects of uterine artery ligation may be mediated, in part, by placental hypoxia-related perinatal leptin deficiency (Nüsken et al. 2016). We in turn developed a mouse model to test the mechanistic hypothesis that central neuronal pathways are involved in the perpetuation of programmed hypertension.

As a foundation for the mechanistic studies to come, we assessed the physiologic implications of natural variation in perinatal growth. Those initial studies replicated human observations that IUGR with persistent neonatal growth restriction increases the risk of hypertension and neurodevelopmental impairment (Hermann et al. 2009) and that estrogen replacement mitigates the hypertensive phenotype otherwise seen in postmenopausal growth-restricted mice (Haskell et al. 2016). Our follow-up investigations revealed that neonatal leptin supplementation prevents the neuropsychiatric impairment and hypertensive response to psychological stress that otherwise follow neonatal growth restriction (Erkonen et al. 2011, Meyer et al. 2014). This therapeutic use of leptin was informed by clinical data showing both
Published by Bioscientifica Ltd 
IUGR and preterm infants undergo critical phases of neuromaturation in the presence of low circulating levels of the neurotrophic hormone leptin.

\section{Perinatal growth restriction, prematurity and circulating leptin levels}

\section{Clinical investigations}

Leptin is primarily secreted by mature adipocytes and circulating leptin levels highly correlate with body mass index. In the fetus, adipose development begins in the 2nd trimester, and by 28 -week gestation, adipose tissue has appeared in the major deposition areas (Poissonnet et al. 1988). Considering the key role leptin plays in organogenesis, it is understandable that redundant systems are in place to ensure the adequacy of circulating leptin levels throughout gestation. Among the contributors to fetal plasma leptin levels, the mother and the placenta play a major role in the first and second trimesters, and the fetus itself becomes a main contributor in the final trimester.

Studies describing the strong association between maternal adiposity, maternal leptin levels and cord blood leptin levels support an important role for transplacental (maternal to fetal) leptin delivery (Varvarigou et al. 1999, Toprak et al. 2004, Ho et al. 2010, Luo et al. 2013). Arguing for alternative leptin sources to support fetal development, other investigations have not observed the same association (Hassink et al. 1997, Clapp \& Kiess 1998, Helland et al. 1998, Hytinantti et al. 1999, Sooranna et al. 2001, Yildiz et al. 2002, Pighetti et al. 2003), and direct maternal-to-fetal leptin transfer has not been identified.

Many investigators have demonstrated a direct correlation between placental weight and cord blood leptin levels (Koistinen et al. 1997, Clapp \& Kiess 1998, Jaquet et al. 1998, Varvarigou et al. 1999, Valūniene et al. 2007). Hassink and coworkers (1997) signaled the potential of the placenta as a contributor to fetal leptin by showing that placental trophoblastic cells secrete leptin, and Yura and coworkers (1998) demonstrated higher leptin levels in umbilical venous blood compared with umbilical arterial blood. Lea and coworkers (2000) subsequently demonstrated that leptin mRNA and protein can be found in the placenta as early as the 1st trimester. In the same study, leptin mRNA and protein were localized to the syncytiotrophoblast and the villous vascular endothelium (Lea et al. 2000). These data suggest that placental leptin is released into both the fetal and maternal circulations. Lepercq and coworkers (2001) later showed that nearly $95 \%$ of placental leptin is secreted into maternal circulation with only $5 \%$ delivered to the fetus. Evidence supporting the physiologic relevance of placental leptin production includes the increased plasma leptin levels seen in pregnant vs non-pregnant women (Matsuda et al. 1999, Schubring et al. 1999, Yokota 2003), and the positive correlation of maternal leptin levels with advancing gestational age (Helland et al. 1998, Visentin et al. 2014). Although the increase in plasma leptin level during pregnancy often correlates with gestational weight gain (Castellano Filho et al. 2013, Marino-Ortega et al. 2015), that association is not observed in obese women (Misra \& Trudeau 2011, Franco-Sena et al. 2015), suggesting that increased fat mass is not the only contributor to the rise in maternal leptin levels during pregnancy. Further support for an adipose-independent source for leptin is found in the studies by Highman and coworkers (1998) showing that the increase in maternal leptin precedes pregnancy-related weight gain, and maternal leptin levels promptly decrease after delivery (Highman et al. 1998, Schubring et al. 1998, Lage et al. 1999).

Placental leptin production and release appear to be regulated by factors including synthetic and endogenous glucocorticoid exposure. Antenatal betamethasone acutely increases maternal leptin but decreases fetal leptin (Marinoni et al. 2008). Those results were replicated by third trimester dexamethasone administration to pregnant rats (Sugden et al. 2001), supporting glucocorticoidinduced reduction in maternal-to-fetal and placental-tofetal leptin passage (Smith \& Waddell 2003). Consistent with those data, growth-restricted fetuses that are exposed to increased endogenous glucocorticoids typically have reduced leptin levels with decreased placental leptin expression, whereas maternal plasma leptin levels are increased (Lepercq et al. 2001, Pighetti et al. 2003, Nezar et al. 2009, Visentin et al. 2014). Similar changes are seen in twin pregnancies with lower placental leptin expression in IUGR-affected twin placenta compared with normal growth twin placenta (Lea et al. 2000). It is notable that other studies have failed to demonstrate a consistent relationship between antenatal glucocorticoid exposure and fetal leptin levels (Shekhawat et al. 2000, Ng et al. 2001, Spear et al. 2001). Beyond adrenal steroids, sex steroids appear to influence leptin levels with male infants having lower levels than females (Hassink et al. 1997, Helland et al. 1998, Ertl et al. 1999, Jaquet et al. 1999, Matsuda et al. 1999, Ong et al. 1999, Ng et al. 2000, 2001, Yokota 2003, Toprak et al. 2004, Valūniene et al. 2007, Chiesa et al. 2008), and an indirect relationship has been

Published by Bioscientifica Ltd 
observed between testosterone and leptin levels (Ertl et al. 1999, Ng et al. 2001, Su et al. 2002). Of note, this sexual dimorphism does not emerge until the final 6 weeks of gestation (Koistinen et al. 1997, Jaquet et al. 1998, Spear et al. 2001, Stoll-Becker et al. 2003). The dependence of leptin levels on maternal-independent factors suggests the fetus helps regulate its own leptin level in the later stages of gestation. It has not been determined clinically whether growth restriction itself reduces adipocyte leptin production independent of fetal fat mass accrual.

Although fetal adipocytes produce leptin as early as 20-week gestation (Lepercq 2001), fetal fat mass more than doubles from 32 to 41 weeks of gestation (Lapillonne et al. 1997). Umbilical cord blood leptin levels thus slowly increase from 18 to 32 weeks of gestation and then increase rapidly until birth (Jaquet et al. 1998, Ertl et al. 1999, Matsuda et al. 1999, Cetin et al. 2000, Park et al. 2001, Lo et al. 2002, Stoll-Becker et al. 2003, Yokota 2003, Fonseca et al. 2004). The importance of fetal fat mass accumulation is supported by the fact that neonatal fat mass has a stronger association with newborn leptin levels than birth weight (Clapp \& Kiess 1998, Jaquet et al. 1998, Fonseca et al. 2004, Toprak et al. 2004). Not surprisingly, by 34-week gestation, intrauterine growth-restricted (IUGR) infants tend to have lower cord blood leptin levels than those appropriate for gestational age infants (Koistinen et al. 1997, Lapillonne et al. 1997, Jaquet et al. 1998, Cetin et al. 2000, Yildiz et al. 2002, Pighetti et al. 2003, Valūniene et al. 2007, Chiesa et al. 2008, Martos-Moreno et al. 2009, Nezar et al. 2009), although some investigations have not observed the same results (Geary et al. 1999, Stoll-Becker et al. 2003, Aydin et al. 2015). Furthermore, leptin levels do not vary between appropriate for gestational age and small for gestational age early preterm infants (Jaquet et al. 1998, Stoll-Becker et al. 2003, Ohkawa et al. 2010, Hellgren et al. 2015). Overall, depending on the population and gestational stage of assessment, cord blood leptin positively correlates with a mix of factors including maternal weight gain during pregnancy, maternal BMI, gestational age, birth weight, ponderal index, infant skin fold thickness and ultrasound-measured adiposity (Cetin et al. 2000, Su et al. 2002, Yildiz et al. 2002, Mantzoros et al. 2009, Brynhildsen et al. 2013, Karakosta et al. 2013). The finding that infant BMI has a greater association with infant plasma leptin levels than birth weight (Fonseca et al. 2004, Toprak et al. 2004) again supports the premise that the development of adipose tissue and the accumulation of fat mass drive the late gestation surge in serum leptin.
Consistent with the importance of transplacental leptin passage even in the later stages of gestation, the physiologic leptin surge is abruptly terminated by delivery for both preterm and term infants (Helland et al. 1998, Hytinantti et al. 1999, Jaquet et al. 1999, Valūniene et al. 2007, Kawamata et al. 2014). After this initial drop, leptin levels remain low for the first week of life (Harigaya et al. 1997, Ertl et al. 1999, Matsuda et al. 1999, Ng et al. 2000, Park et al. 2001, Yokota 2003, Valūniene et al. 2007). Not surprisingly, this postnatal leptin decline does not correlate with the extent of neonatal weight loss (Hytinantti et al. 1999, Jaquet et al. 1999, Matsuda et al. 1999, Park et al. 2001, Valūniene et al. 2007) because a majority of initial weight loss reflects fluid shifts rather than changes in fat mass.

Premature infants face the challenge to grow and develop in the presence of profound leptin deficiency. They are born before the third trimester leptin surge and suffer from a lack of placental and transplacental leptin delivery. There are reports showing a correlation between infant plasma leptin levels and infant gestational age and anthropometric measures (Ng et al. 2000, 2001, Lo et al. 2002, Toprak et al. 2004, Valūniene et al. 2007, Chiesa et al. 2008), but there are also reports suggesting a lack of correlation in preterm infants (Jaquet et al. 1998, Spear et al. 2001, Ho et al. 2010, Ohkawa et al. 2010, Hellgren et al. 2015). The correlation between preterm infant leptin and weight typically becomes significant after infants begin to accrue adipose tissue mass (Enzi et al. 1981). Depending on the gestational age at birth, leptin levels remain below term infant values for 3-8 weeks (Ertl et al. 1999, Ohkawa et al. 2010). Ng and coworkers (2001) studied 61 premature infants and did not observe a statistically significant leptin level increase through day of life 35. Likewise, Toprak and coworkers (2004) showed that an increase in body weight and thickness of subcutaneous adipose tissue eventually led to an increase in leptin levels with adipose tissue appearing to be the main contributor to leptin levels after 30 days of life.

To further quantify the leptin deficiency of prematurity, Hellgren and coworkers (2015) compared 4-week-old preterm infants at 32-week adjusted gestational age to newborn infants at 32-week gestation and noted that former 28 -week preterm infants had leptin levels far below the reference cohort. To our knowledge, this was the first study comparing postnatal leptin levels of preterm infants with 'reference fetus' levels. Those data highlight the concern that preterm infants develop persistent postnatal leptin deficiency during a

Published by Bioscientifica Ltd 
window of developmental vulnerability with potential neurodevelopmental implications. The duration of the postnatal leptin deficiency has not been fully quantified, but recent investigations have confirmed the persistent growth deficiency consistently reported in longitudinal studies (Rochow et al. 2016). For example, Spear and coworkers (2001) followed weekly leptin levels for infants born before 32-week gestation until discharge and did not observe leptin level increase in these infants, and their levels remained significantly below those seen in term infants, even after the preterm cohort reached 40-week corrected gestational age. Likewise, Toprak and coworkers (2004) showed that infants born on average at 34-weeks gestation needed three months to reach serum leptin levels near those of full-term infants. This prolonged low leptin state might represent functional immaturity, a lack of sufficient adipose tissue or the suboptimal nutrition that is frequently seen in premature infants. Further studies are needed to define postnatal leptin changes and the cause-effect relationship between circulating leptin and postnatal growth.

In addition to preterm infants, IUGR infants have decreased postnatal leptin levels (Harigaya et al. 1997, Jaquet et al. 1999). Twin studies by Lea and coworkers (2000) and Sooranna and coworkers (2001) have shown that leptin levels are lower in the growth-restricted twin compared with the normal growth twin, further supporting the theory that leptin is either a cause or consequence of growth deficiency. Similar to the abrupt postnatal leptin decline observed in preterm infants, leptin levels decrease below already low fetal levels in IUGR infants throughout the first week of life (Jaquet et al. 1999, Duncan et al. 2011). With many IUGR infants showing significant catch-up growth during the first year of life, Jaquet and coworkers (1999) evaluated their leptin level changes over 2 years and observed a peak at 6 months.

Beyond caloric intake, the nutritional source influences postnatal leptin levels. Parenteral nutrition and infant formulas do not contain leptin (Resto et al. 2001, O'Connor et al. 2003), but breast milk does (Casabiell et al. 1997, Resto et al. 2001, Miralles et al. 2006). Savino and coworkers (2013) evaluated leptin levels among healthy term infants and then performed follow-up at a median age of 8.8 years. They reported that the infants who were breast fed had higher leptin levels than formula-fed infants. At follow-up, breast-fed infants had lower BMI contributing to the inverse relationship seen between leptin levels in infancy and childhood BMI. The encouragement of breast feeding may help curtail transgenerational obesity as maternal BMI and
Table 1 Factors that increase the risk of perinatal leptin deficiency and programmed hypertension.

Decreased breast milk intake

Male sex

Perinatal growth restriction

Perinatal glucocorticoid exposure

Placental insufficiency or hypoxia

Preterm birth

maternal serum leptin correlate with breast milk leptin levels, and increased breast milk leptin is associated with reduced neonatal growth velocity (Schuster et al. 2011). Studies in rats have confirmed absorption of enterally administered leptin (Casabiell et al. 1997, Sánchez et al. 2005). Unfortunately, at 15 days of life, breast milk leptin is decreased in mothers of growth-restricted infants in comparison with the breast milk provided by mothers of appropriately grown infants (Dundar et al. 2005). Table 1 summarizes the risk factors in common for perinatal leptin deficiency and programmed adult hypertension.

\section{Murine model}

Consistent with their relative short gestation, mice are born with a paucity of adipose tissue and thus have low leptin levels throughout the first 3-4 postnatal days; with increasing adipose deposition and advancing breast milk intake, leptin levels then rise and peak between day 4 and 14 (Ahima et al. 1998, Yura et al. 2005, Delahaye et al. 2008). In the initial investigation of Ahima and coworkers (1998), female mice with normal birth weights were fostered in litters of 5 pups, and leptin levels surged between days 4 and 16. When Yura and coworkers (2005) instead fostered normal birth weight mice into mixed sex litters of 8 or 9 pups, and they observed a smaller leptin surge spanning from day 8 to 16 . In that study, intrauterine growth restriction was induced in additional mice by maternal caloric restriction, and the postnatal leptin surge was skewed toward higher values on days 8-10 with decreasing values on day 16 , leading to the conclusion that IUGR may provoke a 'premature leptin surge'. However, the peaked leptin levels seen in IUGR mice on days 8-10 mirrored the timing of the leptin surge in the study by Ahima and coworkers (1998), as well the investigations by Delahaye and coworkers (2008) showing a postnatal peak on days 4 to 10 in control male rats fostered in litters of 8 pups. In that latter study, maternal perinatal undernutrition did not alter the timing of the leptin surge, but did significantly decrease neonatal leptin levels with parallel interference with hypothalamic development (Delahaye et al. 2008).

Published by Bioscientifica Ltd 


\section{Leptin's role in adult hypertension}

\section{Clinical investigations}

The first insights into the hemodynamic effects of leptin emerged from epidemiological investigations showing that individuals with rare leptin gene mutations were morbidly obese but paradoxically normotensive (Montague et al. 1997, Ozata et al. 1999, Rahmouni et al. 2005). Controversy ensued because early clinical trials of leptin in patients with obesity or lipodystrophy primarily evaluated metabolic outcomes but cursorily reported an absence of leptin-induced cardiovascular manifestations (Heymsfield et al. 1999). The concept of leptin-mediated hypertension gained traction when leptin levels were shown to independently correlate with blood pressure in both postmenopausal women and otherwise healthy men (Ma et al. 2009, Allison et al. 2013, Smith et al. 2015). Elegant preclinical and clinical investigations finally demonstrated the retention of sympathetic activation and hypertension despite selective obesity-related resistance to leptin-induced anorexia (Simonds et al. 2014). Further investigations continue to uncover downstream pathways that can be exploited to target the various effects leptin elicits in the normal physiologic state. For example, hypothalamic leptin receptor expression is found to play a critical role in leptin-induced sympathetic activation and hypertension (Rahmouni \& Morgan 2007, Harlan et al. 2011) with signal transducer and activator of transcription 3 (STAT3) phosphorylation within proopiomelanocortin neurons particularly important in leptin- or stress-evoked hypertension (do Carmo et al. 2011, Dubinion et al. 2013).

\section{Murine models}

We developed a murine model to specifically test the hypothesis that leptin is involved in both the inception and the propagation of perinatal growth restrictionrelated hypertension. After validating the model by demonstrating adult hypertension in intrauterine and/ or neonatal growth-restricted mice (Hermann et al. 2009), we went on to test leptin's therapeutic potential. Given the relative developmental immaturity of newborn mice, the critical third trimester of human adipogenesis and neurodevelopment is analogous to the first two postnatal weeks in mice (Romijn et al. 1991, Grove et al. 2005). Likewise, the leptin surge that occurs in the final months of human gestation coincides with the postnatal day 4 to 14 leptin surge that occurs in well-grown mice. To focus on that critical window of vulnerability, we developed a neonatal growth restriction model by placing pups into litters of 12 to elicit neonatal growth restriction, defined by a weanling weight below the 10th percentile in a manner consistent with WHO guidelines. Mice with incipient growth restriction then receive daily parental leptin supplementation from day 4 to 14 at a dose $(80 \mathrm{ng} / \mathrm{g})$ that recapitulates the leptin levels measured in control mice that are fostered in typical litters of 6 pups. This is a multifactorial model with likely contributions from the same factors operating in preterm humans, including neonatal stress as well as relative neonatal undernutrition. Beyond leptin's neurodevelopmental effects, exogenous leptin can attenuate the adrenal response to neonatal stress (Salzmann et al. 2004). Future studies are needed to determine the acute effect of neonatal leptin supplementation on adrenal function and glucocorticoid levels to test the hypothesis that leptin protects against the hypertensive effects of glucocorticoids.

In adulthood, mice with a history of neonatal growth restriction displayed psychological stress-exacerbated hypertension, neuropsychiatric impairment and altered brain morphology (Erkonen et al. 2011, Meyer et al. 2014). Neonatal leptin supplementation exerted trophic effects on the hypothalamus and normalized all of those findings (Erkonen et al. 2011, Meyer et al. 2014). Mechanistically, neonatal leptin normalization corrected the exaggerated pressor response seen after intracerebroventricular leptin administration, normalized the heightened renal sympathetic nerve response seen after parenteral leptin administration and normalized the increased leptin receptor expression seen in the arcuate nucleus of the hypothalamus (ARC) (Peotta et al. 2016).

Regarding the potential effects of neonatal leptin on adult cardiovascular outcomes; the dose and timing of the intervention are critically important. When neonatal leptin is administered to well-grown mice and rats at supraphysiologic doses $(2.5-6 \mathrm{mg} / \mathrm{kg} /$ day $)$, long-term impairment in leptin-triggered anorexia is observed (Yura et al. 2005, Samuelsson et al. 2013). Vickers and coworkers $(2005,2008)$ have shown that supraphysiologic leptin administration $(2.5 \mathrm{mg} / \mathrm{kg} /$ day $)$ leads to selective leptin resistance in adult mice, with loss of leptin's anorectic effects but retention of leptin-induced hypertension. This inverse correlation between leptin sensitivity and neonatal leptin levels is consistent with the investigations of Rahmouni and coworkers (2005) showing obesity-related (supraphysiologic) hyperleptinemia is associated with selective resistance to leptin's metabolic effects. Finally, the timing of the leptin replacement must match the

Published by Bioscientifica Ltd. 
A

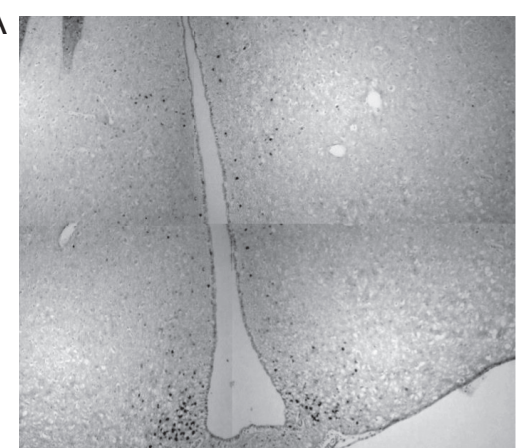

C

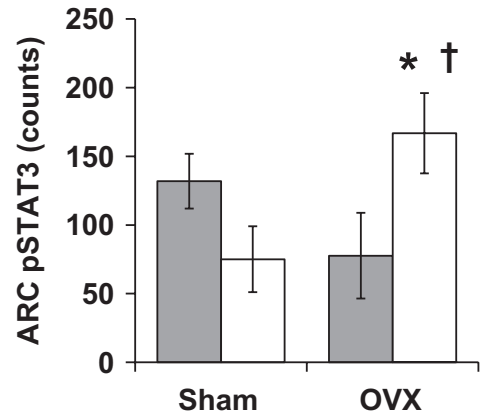

B

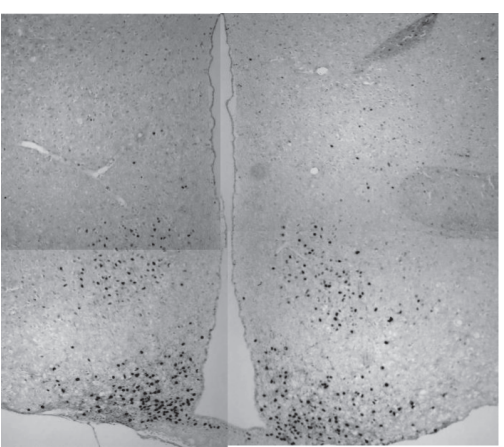

D

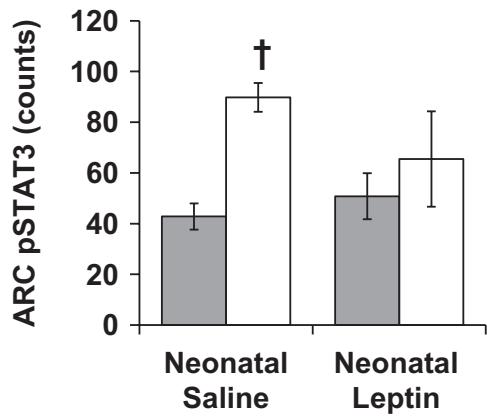

Figure 2

The influence of perinatal growth, ovarian status and neonatal leptin administration on leptin-stimulated hypothalamic signaling in adult mice. These original experiments with C57BL/6J mice (Jackson Laboratory) were approved by the University of lowa Office of Animal Resources. Neonatal growth restriction (GR) was induced by placing mice into litters of 12 rather than 6 pups on postnatal day 1, and GR was confirmed by weanling weights below the 10th percentile for the colony on postnatal day 20. At 2-4 months, female mice underwent bilateral ovariectomy (OVX) or sham surgery (incisions without ovary removal) under inhaled isoflurane anesthesia (4\%, Phoenix Scientific, St Joseph, MO, USA). After 2-3 months of postoperative recovery, a 3-h fast was followed by intraperitoneal injection of murine leptin ( $1 \mathrm{mg} / \mathrm{kg}$, Biomyx Technology, San Diego, CA, USA) $1 \mathrm{~h}$ before transcardiac perfusion fixation during anesthesia with intraperitoneal ketamine ( $262.5 \mathrm{mg} / \mathrm{kg}$, Sigma-Aldrich) and xylazine ( $37.5 \mathrm{mg} / \mathrm{kg}$, Sigma-Aldrich). Coronal cryosections were obtained through the arcuate nucleus of the hypothalamus (ARC), and pSTAT3 immunoreactivity was quantified with anti-phospho-STAT3 (9145, Cell Signaling) followed by detection with ImmPRESS/DAB (MP-7401, Vector Laboratories, Burlingame, CA, USA). Representative immunostains (A, Control-OVX; B, GR-OVX) are composites of 4 higher magnification images. (C) Leptin-stimulated pSTAT3-positive cells counts were influenced by a significant interaction between GR and adult ovarian status (control: closed bars, GR: open bars, $n=4$ or 5 ). OVX significantly increased leptin-evoked pSTAT3 signaling in GR mice ( ${ }^{\dagger} P<0.05$ by ANOVA) such that GR-OVX mice had significantly more pSTAT3 reactive nuclei than control-OVX mice ( $~ P<0.05$ by ANOVA), suggesting that adult ovarian function suppresses GR-associated leptin responsiveness. Compared with control-OVX mice, GR-OVX mice also tended to have more pSTAT3-reactive nuclei in the ventral medial hypothalamus, but the difference did not reach statistical significance (control-OVX $11 \pm 6$, GR-OVX $31 \pm 7$ ). (D) Unlike the significant increase in ARC, pSTAT3 seen in control (neonatal saline) mice that received leptin (open bars) vs saline (closed bars) before perfusion fixation ( ${ }^{+} P<0.05$ by ANOVA), neonatal leptin-treated mice did not have significantly different responses to pre-fixation injection of leptin vs saline, suggesting that neonatal leptin administration decreased adult leptin responsiveness $(n=3$ or 4$)$.

phase of leptin-sensitive neurodevelopment. For example, physiologic leptin administration to lactating rats confers protection from diet-induced obesity in association with favorable alterations in hypothalamic gene expression (Picó et al. 2007, Stocker et al. 2007, Palou et al. 2011). Likewise, placing pups in large litters to elicit neonatal undernutrition leads to a lean, leptin-responsive adult phenotype, whereas placement in small litters to elicit overnutrition predisposes to obesity in association with impaired leptin-triggered hypothalamic STAT3 signaling (Rodrigues et al. 2009). Complementary models once again show that intrauterine growth restriction followed more importantly by accelerated neonatal growth, suppresses adult leptin signaling (Coupé et al. 2012).
Further investigations are required to dissect relevant signaling partners with leading candidates including leptin-induced co-activation of the renin-angiotensin system (Hilzendeger et al. 2012). There are also known interactions between estrogen and leptin, with both hormones acting in part through phosphorylation of STAT3 (Clegg et al. 2006, Gao et al. 2007, Shi \& Brooks 2015). Regarding brain site-specific regulation, the ARC is exquisitely sensitive to environmental modulation of leptin sensitivity and sympathetic tone increases after ARC-targeted leptin microinjections (Münzberg et al. 2004, Harlan et al. 2011, Tanida et al. 2015). Our initial investigations have confirmed interactions among neonatal growth restriction, ovarian function and

Published by Bioscientifica Ltd. 
neonatal leptin administration in the establishment of leptin-induced STAT3 signaling in the ARC (Fig. 2).

\section{Conclusion}

In conclusion, the cumulative evidence indicates that leptin plays a critical role in the perinatal development and that perinatal leptin levels are insufficient to optimize neuroregulatory pathways in both IUGR and preterm infants. In translational mouse models, leptin supplementation targeted to otherwise leptin-deficient growth-restricted mice is sufficient to prevent the development of neurocardiovascular dysfunction and normalize the neural control of renal sympathetic activity and arterial pressure. In addition to mice, leptin supplementation elicits neurotrophic effects in growthrestricted piglets and genetically leptin-deficient humans (Matochik et al. 2005, Attig et al. 2008). Although the neuroanatomic and molecular interactions in the pathways leading to programmed adult hypertension are incompletely understood, the important role that leptin plays in key developmental and regulatory pathways support ongoing investigations into the impact of leptin on the inception and perpetuation of perinatal growth restriction or prematurity-related hypertension.

\section{Declaration of interest}

The authors declare that there is no conflict of interest that could be perceived as prejudicing the impartiality of this review.

\section{Funding}

This work was supported by the National Institutes of Health (grant number HL007485).

\section{Author contribution statement}

B Steinbrekera and R Roghair drafted and revised the article. R Roghair was involved in the design, analysis and interpretation of the primary experiments.

\section{Acknowledgements}

The authors thank their families and colleagues for their invaluable support.

\section{References}

Ahima RS, Prabakaran D \& Flier JS 1998 Postnatal leptin surge and regulation of circadian rhythm of leptin by feeding. Implications for energy homeostasis and neuroendocrine function. Journal of Clinical Investigation 101 1020-1027. (doi:10.1172/JCI1176)
Allison MA, Ix JH, Morgan C, McClelland RL, Rifkin D, Shimbo D \& Criqui MH 2013 Higher leptin is associated with hypertension: the Multi-Ethnic Study of Atherosclerosis. Journal of Human Hypertension 27 617-622. (doi:10.1038/jhh.2013.24)

Attig L, Djiane J, Gertler A, Rampin O, Larcher T, Boukthir S, Anton PM, Madec JY, Gourdou I \& Abdennebi-Najar L 2008 Study of hypothalamic leptin receptor expression in low-birth-weight piglets and effects of leptin supplementation on neonatal growth and development. American Journal of Physiology: Endocrinology and Metabolism 295 E1117-E1125. (doi:10.1152/ajpendo.90542.2008)

Aydin HI, Eser A, Kaygusuz I, Yildirim S, Celik T, Gunduz S \& Kalman S 2015 Adipokine, adropin and endothelin-1 levels in intrauterine growth restricted neonates and their mothers. Journal of Perinatal Medicine 44 669-676. (doi:10.1515/jpm-2014-0353)

Barker DJ, Winter PD, Osmond C, Margetts B \& Simmonds SJ 1989 Weight in infancy and death from ischaemic heart disease. Lancet 2 577-580. (doi:10.1016/S0140-6736(89)90710-1)

Beck S, Wojdyla D, Say L, Betran AP, Merialdi M, Requejo JH, Rubens C, Menon R \& Van Look PF 2010 The worldwide incidence of preterm birth: a systematic review of maternal mortality and morbidity. Bulletin of the World Health Organization 88 31-38. (doi:10.2471/ BLT.08.062554)

Ben-Shlomo Y, McCarthy A, Hughes R, Tilling K, Davies D \& Smith GD. Immediate postnatal growth is associated with blood pressure in young adulthood: the Barry Caerphilly Growth Study. Hypertension 52 638-644. (doi:10.1161/HYPERTENSIONAHA.108.114256)

Bergvall N, Iliadou A, Johansson S, de Faire U, Kramer MS, Pawitan Y, Pedersen NL, Lichtenstein P \& Cnattingius S 2007 Genetic and shared environmental factors do not confound the association between birth weight and hypertension: a study among Swedish twins. Circulation 115 2931-2938. (doi:10.1161/CIRCULATIONAHA.106.674812)

Boguszewski MC, Johannsson G, Fortes LC \& Sverrisdóttir YB 2004 Low birth size and final height predict high sympathetic nerve activity in adulthood. Journal of Hypertension 22 1157-1163. (doi:10.1097/00004872-200406000-00017)

Bonamy AK, Källén K \& Norman M 2012 High blood pressure in 2.5-year-old children born extremely preterm. Pediatrics 129 e1199-e1204. (doi:10.1542/peds.2011-3177)

Bouret SG, Draper SJ \& Simerly RB 2004 Trophic action of leptin on hypothalamic neurons that regulate feeding. Science $\mathbf{3 0 4} 108-110$. (doi:10.1126/science.1095004)

Brynhildsen J, Sydsjö G, Blomberg M, Claesson IM, Theodorsson E, Nyström F, Sydsjö A \& Josefsson A 2013 Leptin and adiponectin in cord blood from children of normal weight, overweight and obese mothers. Acta Paediatrica 102 620-624. (doi:10.1111/apa.12202)

Casabiell X, Piñeiro V, Tomé MA, Peinó R, Diéguez C \& Casanueva FF 1997 Presence of leptin in colostrum and/or breast milk from lactating mothers: a potential role in the regulation of neonatal food intake. Journal of Clinical Endocrinology and Metabolism 82 4270-4273. (doi:10.1210/jcem.82.12.4590)

Castellano Filho DS, do Amaral Correa JO, Dos Santos Ramos P, de Oliveira Montessi M, Aarestrup BJ \& Aarestrup FM 2013 Body weight gain and serum leptin levels of non-overweight and overweight/obese pregnant women. Medical Science Monitor 19 1043-1049. (doi:10.12659/MSM.884027)

Cetin I, Morpurgo PS, Radaelli T, Taricco E, Cortelazzi D, Bellotti M, Pardi G \& Beck-Peccoz P 2000 Fetal plasma leptin concentrations: relationship with different intrauterine growth patterns from 19 weeks to term. Pediatric Research 48 646-651. (doi:10.1203/00006450200011000-00016)

Chiesa C, Osborn JF, Haass C, Natale F, Spinelli M, Scapillati E, Spinelli A \& Pacifico L 2008 Ghrelin, leptin, IGF-1, IGFBP-3, and insulin concentrations at birth: is there a relationship with fetal growth and neonatal anthropometry? Clinical Chemistry 54 550-558. (doi:10.1373/clinchem.2007.095299) http://joe.endocrinology-journals.org

DOI: 10.1530/JOE-16-0273
๑) 2016 Society for Endocrinology Printed in Great Britain 
Clegg DJ, Brown LM, Woods SC \& Benoit SC 2006 Gonadal hormones determine sensitivity to central leptin and insulin. Diabetes $\mathbf{5 5}$ 978-987. (doi:10.2337/diabetes.55.04.06.db05-1339)

Clapp JF 3rd \& Kiess W 1998 Cord blood leptin reflects fetal fat mass. Journal of the Society for Gynecologic Investigation 5 300-303. (doi:10.1016/S1071-5576(98)00028-8)

Coupé B, Grit I, Hulin P, Randuineau G \& Parnet P 2012 Postnatal growth after intrauterine growth restriction alters central leptin signal and energy homeostasis. PLOS ONE 7 e30616. (doi:10.1371/journal. pone.0030616)

Crume TL, Scherzinger A, Stamm E, McDuffie R, Bischoff KJ, Hamman RF \& Dabelea D 2014 The long-term impact of intrauterine growth restriction in a diverse U.S. cohort of children: the EPOCH study. Obesity 22 608-615. (doi:10.1002/oby.20565)

Curhan GC, Willett WC, Rimm EB, Spiegelman D, Ascherio AL \& Stampfer MJ 1999 Prevention of cardiovascular disease: birthweight and adult hypertension, diabetes mellitus, and obesity in US men. Circulation 94 3246-3250. (doi:10.1161/01.CIR.94.12.3246)

Dagle JM, Fisher TJ, Haynes SE, Berends SK, Brophy PD, Morriss FH Jr \& Murray JC 2011 Cytochrome P450 (CYP2D6) genotype is associated with elevated systolic blood pressure in preterm infants after discharge from the neonatal intensive care unit. Journal of Pediatrics 159 104-109. (doi:10.1016/j.jpeds.2011.01.002)

de Jong F, Monuteaux MC, van Elburg RM, Gillman MW \& Belfort MB 2012 Systematic review and meta-analysis of preterm birth and later systolic blood pressure. Hypertension 59 226-234. (doi:10.1161/ HYPERTENSIONAHA.111.181784)

Delahaye F, Breton C, Risold PY, Enache M, Dutriez-Casteloot I, Laborie C, Lesage J \& Vieau D 2008 Maternal perinatal undernutrition drastically reduces postnatal leptin surge and affects the development of arcuate nucleus proopiomelanocortin neurons in neonatal male rat pups. Endocrinology 149 470-475. (doi:10.1210/en.2007-1263)

do Carmo JM, da Silva AA, Cai Z, Lin S, Dubinion JH \& Hall JE 2011 Control of blood pressure, appetite, and glucose by leptin in mice lacking leptin receptors in proopiomelanocortin neurons. Hypertension 57 918-926. (doi:10.1161/HYPERTENSIONAHA.110.161349)

Dubinion JH, do Carmo JM, Adi A, Hamza S, da Silva AA \& Hall JE 2013 Role of proopiomelanocortin neuron Stat 3 in regulating arterial pressure and mediating the chronic effects of leptin. Hypertension $\mathbf{6 1}$ 1066-1074. (doi:10.1161/HYPERTENSIONAHA.111.00020)

Duncan AF, Heyne RJ, Morgan JS, Ahmad N \& Rosenfeld CR 2011 Elevated systolic blood pressure in preterm very-low-birthweight infants $\leq 3$ years of life. Pediatric Nephrology 26 1115-1121. (doi:10.1007/s00467-011-1833-x)

Dundar NO, Anal O, Dundar B, Ozkan H, Caliskan S \& Büyükgebiz A 2005 Longitudinal investigation of the relationship between breast milk leptin levels and growth in breast-fed infants. Journal of Pediatric Endocrinology and Metabolism 18 181-187. (doi:10.1515/ jpem.2005.18.2.181)

Dusick AM, Poindexter BB, Ehrenkranz RA \& Lemons JA 2003 Growth failure in the preterm infant: can we catch up? Seminars in Perinatology 27 302-310. (doi:10.1016/S0146-0005(03)00044-2)

Enzi G, Zanardo V, Caretta F, Inelmen EM \& Rubaltelli F 1981 Intrauterine growth and adipose tissue development. American Journal of Clinical Nutrition 34 1785-1790.

Eriksson JG, Forsén TJ, Kajantie E, Osmond C \& Barker DJ 2007 Childhood growth and hypertension in later life. Hypertension 49 1415-1421. (doi:10.1161/HYPERTENSIONAHA.106.085597)

Erkonen GE, Hermann GM, Miller RL, Thedens DL, Nopoulos PC, Wemmie JA \& Roghair RD 2011 Neonatal leptin administration alters regional brain volumes and blocks neonatal growth restriction-induced behavioral and cardiovascular dysfunction in male mice. Pediatric Research 69 406-412. (doi:10.1203/ PDR.0b013e3182110c7d)

Ertl T, Funke S, Sárkány I, Szabó I, Rascher W, Blum WF \& Sulyok E 1999 Postnatal changes of leptin levels in full-term and preterm neonates: their relation to intrauterine growth, gender and testosterone. Biology of the Neonate 75 167-176. (doi:10.1159/000014093)

Fonseca VM, Sichieri R, Moreira ME \& Moura AS 2004 Early postnatal growth in preterm infants and cord blood leptin. Journal of Perinatology 24 751-756. (doi:10.1038/sj.jp.7211188)

Franco-Sena AB, Rebelo F, Pinto T, Farias DR, Silveira GE, Mendes RH, Henriques VT \& Kac G 2015 The effect of leptin concentrations and other maternal characteristics on gestational weight gain is different according to pre-gestational BMI: results from a prospective cohort. British Journal of Obstetrics and Gynaecology 123 1804-1813. (doi:10.1111/1471-0528.13826)

Gao Q, Mezei G, Nie Y, Rao Y, Choi CS, Bechmann I, Leranth C, Toran-Allerand D, Priest CA, Roberts JL, et al. 2007 Anorectic estrogen mimics leptin's effect on the rewiring of melanocortin cells and Stat3 signaling in obese animals. Nature Medicine 13 89-94. (doi:10.1038/ $\mathrm{nm} 1525)$

Geary M, Herschkovitz R, Pringle PJ, Rodeck CH \& Hindmarsh PC 1999 Ontogeny of serum leptin concentrations in the human. Clinical Endocrinology 51 189-192. (doi:10.1046/j.1365-2265.1999.00758.x)

Grant N, Hamer M \& Steptoe A 2009 Social isolation and stress-related cardiovascular, lipid, and cortisol responses. Annals of Behavioral Medicine 37 29-37. (doi:10.1007/s12160-009-9081-z)

Grove KL, Grayson BE, Glavas MM, Xiao XQ \& Smith MS 2005 Development of metabolic systems. Physiology and Behavior $\mathbf{8 6}$ 646-660. (doi:10.1016/j.physbeh.2005.08.063)

Gunay F, Alpay H, Gokce I \& Bilgen H 2014 Is late-preterm birth a risk factor for hypertension in childhood? European Journal of Pediatrics 173 751-756. (doi:10.1007/s00431-013-2242-x)

Hack M, Schluchter M, Cartar L, Rahman M, Cuttler L \& Borawski E 2003 Growth of very low birth weight infants to age 20 years. Pediatrics 112 e30-e38. (doi:10.1542/peds.112.1.e30)

Hack M, Schluchter M, Margevicius S, Andreias L, Taylor HG \& Cuttler L 2014 Trajectory and correlates of growth of extremely-low-birthweight adolescents. Pediatric Research 75 358-366. (doi:10.1038/ pr.2013.209)

Harigaya A, Nagashima K, Nako Y \& Morikawa A 1997 Relationship between concentration of serum leptin and fetal growth. Journal of Clinical Endocrinology and Metabolism 82 3281-3284. (doi:10.1210/ jcem.82.10.4321)

Harlan SM, Morgan DA, Agassandian K, Guo DF, Cassell MD, Sigmund CD, Mark AL \& Rahmouni K 2011 Ablation of the leptin receptor in the hypothalamic arcuate nucleus abrogates leptininduced sympathetic activation. Circulation Research 108 808-812. (doi:10.1161/CIRCRESAHA.111.240226)

Haskell SE, Peotta V, Reinking BE, Zhang C, Zhu V, Kenkel EJ \& Roghair RD 2016 Oral oestrogen reverses ovariectomy-induced morning surge hypertension in growth-restricted mice. Clinical Science 130 613-623. (doi:10.1042/CS20150693)

Hassink SG, de Lancey E, Sheslow DV, Smith-Kirwin SM, O'Connor DM, Considine RV, Opentanova I, Dostal K, Spear ML, Leef K, et al. 1997 Placental leptin: an important new growth factor in intrauterine and neonatal development? Pediatrics 100 E1. (doi:10.1542/peds.100.1.e1)

Helland IB, Reseland JE, Saugstad OD \& Drevon CA 1998 Leptin levels in pregnant women and newborn infants: gender differences and reduction during the neonatal period. Pediatrics $\mathbf{1 0 1}$ E12. (doi:10.1542/peds.101.3.e12)

Hellgren G, Engström E, Smith LE, Löfqvist C \& Hellström A 2015 Effect of preterm birth on postnatal apolipoprotein and adipocytokine profiles. Neonatology 108 16-22. (doi:10.1159/000381278)

Hermann GM, Miller RL, Erkonen GE, Dallas LM, Hsu E, Zhu V \& Roghair RD 2009 Neonatal catch up growth increases diabetes susceptibility but improves behavioral and cardiovascular outcomes of low birth weight male mice. Pediatric Research 66 53-58. (doi:10.1203/PDR.0b013e3181a7c5fd)

Heymsfield SB, Greenberg AS, Fujioka K, Dixon RM, Kushner R, Hunt T, Lubina JA, Patane J, Self B, Hunt P, et al. 1999 Recombinant 
leptin for weight loss in obese and lean adults: a randomized, controlled, dose-escalation trial. JAMA 282 1568-1575. (doi:10.1001/ jama.282.16.1568)

Highman TJ, Friedman JE, Huston LP, Wong WW \& Catalano PM 1998 Longitudinal changes in maternal serum leptin concentrations, body composition, and resting metabolic rate in pregnancy. American Journal of Obstetrics and Gynecology 178 1010-1015. (doi:10.1016/ S0002-9378(98)70540-X)

Hilzendeger AM, Morgan DA, Brooks L, Dellsperger D, Liu X, Grobe JL, Rahmouni K, Sigmund CD \& Mark AL. A brain leptin-renin angiotensin system interaction in the regulation of sympathetic nerve activity. American Journal of Physiology: Heart and Circulatory Physiology 303 H197-H206. (doi:10.1152/ajpheart.00974.2011)

Ho SP, Wang LJ, Cheng I, Chen YL, Sung TC, Jow GM \& Mu SC 2010 Association of plasma leptin levels with maternal body weight and body mass index in premature and term newborns. Pediatrics and Neonatology 51 19-25. (doi:10.1016/S1875-9572(10)60005-8)

Hytinantti T, Koistinen HA, Koivisto VA, Karonen SL \& Andersson S 1999 Changes in leptin concentration during the early postnatal period: adjustment to extrauterine life? Pediatric Research 45 197-201. (doi:10.1203/00006450-199902000-00007)

Intapad S, Tull FL, Brown AD, Dasinger JH, Ojeda NB, Fahling JM \& Alexander BT 2013 Renal denervation abolishes the age-dependent increase in blood pressure in female intrauterine growth-restricted rats at 12 months of age. Hypertension 61 828-834. (doi:10.1161/ HYPERTENSIONAHA.111.00645)

Intapad S, Ojeda NB, Dasinger JH \& Alexander BT 2014 Sex differences in the developmental origins of cardiovascular disease. Physiology 29 122-132. (doi:10.1152/physiol.00045.2013)

Jaquet D, Leger J, Levy-Marchal C, Oury JF \& Czernichow P 1998 Ontogeny of leptin in human fetuses and newborns: effect of intrauterine growth retardation on serum leptin concentrations. Journal of Clinical Endocrinology and Metabolism 83 1243-1246. (doi:10.1210/jcem.83.4.4731)

Jaquet D, Leger J, Tabone MD, Czernichow P \& Levy-Marchal C 1999 High serum leptin concentrations during catch-up growth of children born with intrauterine growth retardation. Journal of Clinical Endocrinology and Metabolism 84 1949-1953. (doi:10.1210/ jc.84.6.1949)

Johansson S, Iliadou A, Bergvall N, Tuvemo T, Norman M \& Cnattingius S 2005 Risk of high blood pressure among young men increases with the degree of immaturity at birth. Circulation 112 3430-3436. (doi:10.1161/CIRCULATIONAHA.105.540906)

Johansson S, Norman M, Legnevall L, Dalmaz Y, Lagercrantz H \& Vanpée M 2007 Increased catecholamines and heart rate in children with low birth weight: perinatal contributions to sympathoadrenal overactivity. Journal of Internal Medicine 261 480-487. (doi:10.1111/ j.1365-2796.2007.01776.x)

Jones A, Beda A, Ward AM, Osmond C, Phillips DI, Moore VM \& Simpson DM 2007 Size at birth and autonomic function during psychological stress. Hypertension 49 548-555. (doi:10.1161/01. HYP.0000257196.13485.9b)

Jones A, Beda A, Osmond C, Godfrey KM, Simpson DM \& Phillips DI 2008 Sex-specific programming of cardiovascular physiology in children. European Heart Journal 29 2164-2170. (doi:10.1093/ eurheartj/ehn292)

Karakosta P, Georgiou V, Fthenou E, Papadopoulou E, Roumeliotaki T, Margioris A, Castanas E, Kampa M, Kogevinas M \& Chatzi L 2013 Maternal weight status, cord blood leptin and fetal growth: a prospective mother-child cohort study (Rhea study). Paediatric Perinatology Epidemiology 27 461-471. (doi:10.1111/ppe.12074)

Katkhuda R, Peterson ES, Roghair RD, Norris AW, Scholz TD \& Segar JL 2012 Sex-specific programming of hypertension in offspring of late-gestation diabetic rats. Pediatric Research 72 352-361. (doi:10.1038/pr.2012.93)
Kawamata R, Suzuki Y, Yada Y, Koike Y, Kono Y, Yada T \& Takahashi N 2014 Gut hormone profiles in preterm and term infants during the first 2 months of life. Journal of Pediatric Endocrinology and Metabolism 27 717-723. (doi:10.1515/jpem-2013-0385)

Kerkhof GF, Breukhoven PE, Leunissen RW, Willemsen RH \& Hokken-Koelega AC 2012 Does preterm birth influence cardiovascular risk in early adulthood? Journal of Pediatrics $\mathbf{1 6 1}$ 390-396. (doi:10.1016/j.jpeds.2012.03.048)

Koistinen HA, Koivisto VA, Andersson S, Karonen SL, Kontula K, Oksanen L \& Teramo KA 1997 Leptin concentration in cord blood correlates with intrauterine growth. Journal of Clinical Endocrinology and Metabolism 82 3328-3330. (doi:10.1210/jc.82.10.3328)

Lage M, Garcia-Mayor RV, Tomé MA, Cordido F, Valle-Inclan F, Considine RV, Caro JF, Dieguez C \& Casanueva FF 1999 Serum leptin levels in women throughout pregnancy and the postpartum period and in women suffering spontaneous abortion. Clinical Endocrinology 50 211-216. (doi:10.1046/j.1365-2265.1999.00637.x)

Lapillonne A, Braillon P, Claris O, Chatelain PG, Delmas PD \& Salle BL 1997 Body composition in appropriate and in small for gestational age infants. Acta Paediatrica 86 196-200. (doi:10.1111/j.1651-2227.1997.tb08868.x)

Lea RG, Howe D, Hannah LT, Bonneau O, Hunter L \& Hoggard N 2000 Placental leptin in normal, diabetic and fetal growth-retarded pregnancies. Molecular Human Reproduction 6 763-769. (doi:10.1093/ molehr/6.8.763)

Lepercq J, Challier JC, Guerre-Millo M, Cauzac M, Vidal H \& Hauguel-de Mouzon S 2001 Prenatal leptin production: evidence that fetal adipose tissue produces leptin. Journal of Clinical Endocrinology and Metabolism 86 2409-2413. (doi:10.1210/jcem.86.6.7529)

Lewandowski AJ, Augustine D, Lamata P, Davis EF, Lazdam M, Francis J, McCormick K, Wilkinson AR, Singhal A, Lucas A, et al. 2013 Preterm heart in adult life: cardiovascular magnetic resonance reveals distinct differences in left ventricular mass, geometry, and function. Circulation 127 197-206. (doi:10.1161/ CIRCULATIONAHA.112.126920)

Lo HC, Tsao LY, Hsu WY, Chen HN, Yu WK \& Chi CY 2002 Relation of cord serum levels of growth hormone, insulin-like growth factors, insulin-like growth factor binding proteins, leptin, and interleukin-6 with birth weight, birth length, and head circumference in term and preterm neonates. Nutrition 18 604-608. (doi:10.1016/S08999007(01)00811-5)

Luo ZC, Nuyt AM, Delvin E, Fraser WD, Julien P, Audibert F, Girard I, Shatenstein B, Deal C, Grenier E, et al. 2013 Maternal and fetal leptin, adiponectin levels and associations with fetal insulin sensitivity. Obesity 21 210-216. (doi:10.1002/oby.20250)

Ma D, Feitosa MF, Wilk JB, Laramie JM, Yu K, Leiendecker-Foster C, Myers RH, Province MA \& Borecki IB 2009 Leptin is associated with blood pressure and hypertension in women from the National Heart, Lung, and Blood Institute Family Heart Study. Hypertension 53 473-479. (doi:10.1161/HYPERTENSIONAHA.108.118133)

Mantzoros CS, Rifas-Shiman SL, Williams CJ, Fargnoli JL, Kelesidis T \& Gillman MW 2009 Cord blood leptin and adiponectin as predictors of adiposity in children at 3 years of age: a prospective cohort study. Pediatrics 123 682-689. (doi:10.1542/peds.2008-0343)

Marino-Ortega LA, Molina-Bello A, Polanco-García JC, Muñoz-Valle JF, Salgado-Bernabé AB, Guzmán-Guzmán IP \& Parra-Rojas I 2015 Correlation of leptin and soluble leptin receptor levels with anthropometric parameters in mother-newborn pairs. International Journal of Clinical and Experimental Medicine $\mathbf{8}$ 11260-11267.

Marinoni E, Letizia C, Ciardo F, Corona G, Moscarini M \& Di Iorio R 2008 Effects of prenatal betamethasone administration on leptin and adiponectin concentrations in maternal and fetal circulation. American Journal of Obstetrics and Gynecology 199 141.e1-141.e6. (doi:10.1016/j.ajog.2008.02.047) http://joe.endocrinology-journals.org

DOI: $10.1530 / J O E-16-0273$ (c) 2016 Society for Endocrinology Printed in Great Britain 
Martos-Moreno GA, Barrios V, Sáenz de Pipaón M, Pozo J, Dorronsoro I, Martínez-Biarge M, Quero J \& Argente J 2009 Influence of prematurity and growth restriction on the adipokine profile, IGF1, and ghrelin levels in cord blood: relationship with glucose metabolism. European Journal of Endocrinology 161 381-389. (doi:10.1530/EJE-09-0193)

Matochik JA, London ED, Yildiz BO, Ozata M, Caglayan S, DePaoli AM, Wong ML \& Licinio J 2005 Effect of leptin replacement on brain structure in genetically leptin-deficient adults. Journal of Clinical Endocrinology and Metabolism 90 2851-2854. (doi:10.1210/jc.20041979)

Matsuda J, Yokota I, Iida M, Murakami T, Yamada M, Saijo T, Naito E, Ito M, Shima K \& Kuroda Y 1999 Dynamic changes in serum leptin concentrations during the fetal and neonatal periods. Pediatric Research 45 71-75. (doi:10.1203/00006450-199901000-00012)

Meyer LR, Zhu V, Miller A \& Roghair RD 2014 Growth restriction, leptin, and the programming of adult behavior in mice. Behavioural Brain Research 275 131-135. (doi:10.1016/j.bbr.2014.08.054)

Miles KL, McDonnell BJ, Maki-Petaja KM, Yasmin, Cockcroft JR, Wilkinson IB \& McEniery CM; Enigma Study investigators 2011 The impact of birth weight on blood pressure and arterial stiffness in later life: the Enigma Study. Journal of Hypertension 29 2324-2331. (doi:10.1097/HJH.0b013e32834d0ca1)

Miller SL, Huppi PS \& Mallard C 2016 The consequences of fetal growth restriction on brain structure and neurodevelopmental outcome. Journal of Physiology 594 807-823. (doi:10.1113/JP271402)

Miralles O, Sanchez J, Palou A \& Pico C 2006 A physiological role of breast milk leptin in body weight control in developing infants. Obesity 14 1371-1377. (doi:10.1038/oby.2006.155)

Misra VK \& Trudeau S 2011 The influence of overweight and obesity on longitudinal trends in maternal serum leptin levels during pregnancy. Obesity 19 416-421. (doi:10.1038/oby.2010.172)

Mizuno M, Siddique K, Baum M \& Smith SA 2013 Prenatal programming of hypertension induces sympathetic overactivity in response to physical stress. Hypertension 61 180-186. (doi:10.1161/ HYPERTENSIONAHA.112.199356)

Montague CT, Farooqi IS, Whitehead JP, Soos MA, Rau H, Wareham NJ, Sewter CP, Digby JE, Mohammed SN, Hurst JA, et al. 1997 Congenital leptin deficiency is associated with severe early-onset obesity in humans. Nature 387 903-908. (doi:10.1038/43185)

Münzberg H, Flier JS \& Bjørbaek C 2004 Region-specific leptin resistance within the hypothalamus of diet-induced obese mice. Endocrinology 145 4880-4889. (doi:10.1210/en.2004-0726)

Nezar MA, el-Baky AM, Soliman OA, Abdel-Hady HA, Hammad AM \& Al-Haggar MS 2009 Endothelin-1 and leptin as markers of intrauterine growth restriction. Indian Journal of Pediatrics 76 485-488. (doi:10.1007/s12098-009-0079-0)

Ng PC, Lam CW, Lee CH, Wong GW, Fok TF, Chan IH, Ma KC \& Wong E 2000 Leptin and metabolic hormones in preterm newborns. Archives of Disease in Childhood. Fetal and Neonatal Edition 83 F198-F202. (doi:10.1136/fn.83.3.F198)

Ng PC, Lam CW, Lee CH, Wong GW, Fok TF, Wong E, Chan IH \& Ma KC 2001 Changes of leptin and metabolic hormones in preterm infants: a longitudinal study in early postnatal life. Clinical Endocrinology $\mathbf{5 4}$ 673-680. (doi:10.1046/j.1365-2265.2001.01231.x)

Nüsken E, Wohlfarth M, Lippach G, Rauh M, Schneider H, Dötsch J \& Nüsken KD 2016 Reduced perinatal leptin availability may contribute to adverse metabolic programming in a rat model of utero-placental insufficiency. Endocrinology 157 1813-1825. (doi:10.1210/en.20151898)

O'Connor D, Funanage V, Locke R, Spear M \& Leef K 2003 Leptin is not present in infant formulas. Journal of Endocrinological Investigation $\mathbf{2 6}$ 490. (doi:10.1007/bf03345207)

Ohkawa N, Shoji H, Kitamura T, Suganuma H, Yoshikawa N, Suzuki M, Lee T, Hisata K \& Shimizu T 2010 IGF-I, leptin and active ghrelin levels in very low birth weight infants during the first 8 weeks of life. Acta Paediatrica 99 37-41. (doi:10.1111/j.1651-2227.2009.01516.x)
Ojeda NB, Grigore D, Robertson EB \& Alexander BT 2007 Estrogen protects against increased blood pressure in postpubertal female growth restricted offspring. Hypertension 50 679-685 (doi:10.1161/ HYPERTENSIONAHA.107.091785)

Ong KK, Ahmed ML, Sherriff A, Woods KA, Watts A, Golding J \& Dunger DB 1999 Cord blood leptin is associated with size at birth and predicts infancy weight gain in humans. ALSPAC Study Team. Avon Longitudinal Study of Pregnancy and Childhood. Journal of Clinical Endocrinology and Metabolism 84 1145-1148. (doi:10.1210/ jcem.84.3.5657)

Ozata M, Ozdemir IC \& Licinio J 1999 Human leptin deficiency caused by a missense mutation: multiple endocrine defects, decreased sympathetic tone, and immune system dysfunction indicate new targets for leptin action, greater central than peripheral resistance to the effects of leptin, and spontaneous correction of leptin-mediated defects. Journal of Clinical Endocrinology and Metabolism 84 3686-3695. (doi:10.1210/jcem.84.10.5999)

Palou M, Picó C, McKay JA, Sánchez J, Priego T, Mathers JC \& Palou A 2011 Protective effects of leptin during the suckling period against later obesity may be associated with changes in promoter methylation of the hypothalamic pro-opiomelanocortin gene. British Journal of Nutrition 106 769-778. (doi:10.1017/ S0007114511000973)

Park MJ, Namgung R, Kim JN \& Kim DH 2001 Serum leptin, IGF-I and insulin levels in preterm infants receiving parenteral nutrition during the first week of life. Journal of Pediatric Endocrinology and Metabolism 14 429-433. (doi:10.1515/jpem.2001.14.4.429)

Peotta V, Rahmouni K, Segar JL, Morgan DA, Pitz KM, Rice OM \& Roghair RD 2016 Neonatal growth restriction-related leptin deficiency enhances leptin-triggered sympathetic activation and central angiotensin II receptor-dependent stress-evoked hypertension. Pediatric Research 80 244-251. (doi:10.1038/pr.2016.64)

Picó C, Oliver P, Sánchez J, Miralles O, Caimari A, Priego T \& Palou A 2007 The intake of physiological doses of leptin during lactation in rats prevents obesity in later life. International Journal of Obesity $\mathbf{3 1}$ 1199-1209. (doi:10.1038/sj.ijo.0803585)

Pighetti M, Tommaselli GA, D’Elia A, Di Carlo C, Mariano A, Di Carlo A \& Nappi C 2003 Maternal serum and umbilical cord blood leptin concentrations with fetal growth restriction. Obstetrics and Gynecology 102 535-543. (doi:10.1016/s0029-7844(03)00668-9)

Pinto S, Roseberry AG, Liu H, Diano S, Shanabrough M, Cai X, Friedman JM \& Horvath TL 2004 Rapid rewiring of arcuate nucleus feeding circuits by leptin. Science $\mathbf{3 0 4}$ 110-115. (doi:10.1126/ science.1089459)

Poissonnet CM, LaVelle M \& Burdi AR 1988 Growth and development of adipose tissue. Journal of Pediatrics 113 1-9. (doi:10.1016/S00223476(88)80520-1)

Pyhälä R, Räikkönen K, Feldt K, Andersson S, Hovi P, Eriksson JG, Järvenpää AL \& Kajantie E 2009 Blood pressure responses to psychosocial stress in young adults with very low birth weight: Helsinki study of very low birth weight adults. Pediatrics 123 731-734. (doi:10.1542/peds.2008-0277)

Rahmouni K \& Morgan DA 2007 Hypothalamic arcuate nucleus mediates the sympathetic and arterial pressure responses to leptin. Hypertension 49 647-652. (doi:10.1161/01.HYP.0000254827.59792.b2)

Rahmouni K, Morgan DA, Morgan GM, Mark AL \& Haynes WG 2005 Role of selective leptin resistance in diet-induced obesity hypertension. Diabetes 54 2012-2018. (doi:10.2337/ diabetes.54.7.2012)

Resto M, O'Connor D, Leef K, Funanage V, Spear M \& Locke R 2001 Leptin levels in preterm human breast milk and infant formula. Pediatrics 108 E15. (doi:10.1542/peds.108.1.e15)

Rochow N, Raja P, Liu K, Fenton T, Landau-Crangle E, Göttler S, Jahn A, Lee S, Seigel S, Campbell D, et al. 2016 Physiological adjustment to postnatal growth trajectories in healthy preterm infants. Pediatric Research 79 870-879. (doi:10.1038/pr.2016.15) 
Rodrigues AL, de Moura EG, Passos MC, Dutra SC \& Lisboa PC 2009 Postnatal early overnutrition changes the leptin signalling pathway in the hypothalamic-pituitary-thyroid axis of young and adult rats. Journal of Physiology 587 2647-2661. (doi:10.1113/ jphysiol.2009.169045)

Roghair RD \& Aldape G 2007 Naturally occurring perinatal growth restriction in mice programs cardiovascular and endocrine function in a sex- and strain-dependent manner. Pediatric Research 62 399-404. (doi:10.1203/PDR.0b013e31813cbf16)

Roghair RD, Segar JL, Volk KA, Chapleau MW, Dallas LM, Sorenson AR, Scholz TD \& Lamb FS 2009 Vascular nitric oxide and superoxide anion contribute to sex-specific programmed cardiovascular physiology in mice. American Journal of Physiology: Regulatory Integrative Comprehensive Physiology 296 R651-R662. (doi:10.1152/ ajpregu.90756.2008)

Romijn HJ, Hofman MA \& Gramsbergen A 1991 At what age is the developing cerebral cortex of the rat comparable to that of the full-term newborn human baby? Early Human Development 26 61-67. (doi:10.1016/0378-3782(91)90044-4)

Salzmann C, Otis M, Long H, Roberge C, Gallo-Payet N \& Walker CD 2004 Inhibition of steroidogenic response to adrenocorticotropin by leptin: implications for the adrenal response to maternal separation in neonatal rats. Endocrinology 145 1810-1822. (doi:10.1210/en.20031514)

Samuelsson AM, Clark J, Rudyk O, Shattock MJ, Bae SE, South T, Pombo J, Redington K, Uppal E, Coen CW, et al. 2013 Experimental hyperleptinemia in neonatal rats leads to selective leptin responsiveness, hypertension, and altered myocardial function. Hypertension 62 627-633. (doi:10.1161/ HYPERTENSIONAHA.111.00691)

Sánchez J, Oliver P, Miralles O, Ceresi E, Picó C \& Palou A 2005 Leptin orally supplied to neonate rats is directly uptaken by the immature stomach and may regulate short-term feeding. Endocrinology 146 2575-2582. (doi:10.1210/en.2005-0112)

Savino F, Liguori SA, Benetti S, Sorrenti M, Fissore MF \& Cordero di Montezemolo L2013 High serum leptin levels in infancy can potentially predict obesity in childhood, especially in formula-fed infants. Acta Paediatrica 102 e455-e459. (doi:10.1111/apa.12354)

Schäffer L, Müller-Vizentini D, Burkhardt T, Rauh M, Ehlert U \& Beinder E 2009 Blunted stress response in small for gestational age neonates. Pediatric Research 65 231-235. (doi:10.1203/pdr.0b013e318191fb44)

Schubring C, Englaro P, Siebler T, Blum WF, Demirakca T, Kratzsch J \& Kiess W 1998 Longitudinal analysis of maternal serum leptin levels during pregnancy, at birth and up to six weeks after birth: relation to body mass index, skinfolds, sex steroids and umbilical cord blood leptin levels. Hormone Research 50 276-283. (doi:10.1159/000023290)

Schubring C, Prohaska F, Prohaska A, Englaro P, Blum W, Siebler T, Kratzsch J \& Kiess W 1999 Leptin concentrations in maternal serum and amniotic fluid during the second trimenon: differential relation to fetal gender and maternal morphometry. European Journal of Obstetrics and Gynecology and Reproductive Biology 86 151-157. (doi:10.1016/S0301-2115(99)00059-7)

Schuster S, Hechler C, Gebauer C, Kiess W \& Kratzsch J 2011 Leptin in maternal serum and breast milk: association with infants' body weight gain in a longitudinal study over 6 months of lactation. Pediatric Research 70 633-637. (doi:10.1203/PDR.0b013e31823214ea)

Sehgal A, Doctor T \& Menahem S 2013 Cardiac function and arterial biophysical properties in small for gestational age infants: postnatal manifestations of fetal programming. Journal of Pediatrics 163 1296-1300. (doi:10.1016/j.jpeds.2013.06.030)

Shekhawat PS, Garland JS, Alex C, Sasidharan P, Mick G \& McCormick KL 2000 Cord blood and postnatal serum leptin and its relationship to steroid use and growth in sick preterm infants. Journal of Pediatric Endocrinology and Metabolism 13 1571-1576. (doi:10.1515/ jpem.2000.13.9.1571)
Shi Z \& Brooks VL 2015 Leptin differentially increases sympathetic nerve activity and its baroreflex regulation in female rats: role of oestrogen. Journal of Physiology 593 1633-1647. (doi:10.1113/ jphysiol.2014.284638)

Simonds SE, Pryor JT, Ravussin E, Greenway FL, Dileone R, Allen AM, Bassi J, Elmquist JK, Keogh JM, Henning E, et al. 2014 Leptin mediates the increase in blood pressure associated with obesity. Cell 159 1404-1416. (doi:10.1016/j.cell.2014.10.058)

Sipola-Leppänen M, Vääräsmäki M, Tikanmäki M, Matinolli HM, Miettola S, Hovi P, Wehkalampi K, Ruokonen A, Sundvall J, Pouta A, et al. 2015 Cardiometabolic risk factors in young adults who were born preterm. American Journal of Epidemiology 181 861-873. (doi:10.1093/aje/kwu443)

Smith JT \& Waddell BJ 2003 Leptin distribution and metabolism in the pregnant rat: transplacental leptin passage increases in late gestation but is reduced by excess glucocorticoids. Endocrinology 144 3024-3030. (doi:10.1210/en.2003-0145)

Smith W, Schutte R, Huisman HW, Van Rooyen JM, Ware LJ, Fourie CM, Mels CM, Kruger R, McCarthy N \& Schutte AE 2015 Leptin is positively associated with blood pressure in African men with a low body mass index: the SAfrEIC study. Hormone and Metabolic Research 47 145-151. (doi:10.1055/s-0034-1389926)

Sooranna SR, Ward S \& Bajoria R 2001 Fetal leptin influences birth weight in twins with discordant growth. Pediatric Research 49 667-672. (doi:10.1203/00006450-200105000-00010)

Spear ML, Hassink SG, Leef K, O'Connor DM, Kirwin SM, Locke R, Gorman R \& Funanage VL 2001 Immaturity or starvation? Longitudinal study of leptin levels in premature infants. Biology of the Neonate 80 35-40. (doi:10.1159/000047117)

Stocker CJ, Wargent E, O'Dowd J, Cornick C, Speakman JR, Arch JR $\&$ Cawthorne MA 2007 Prevention of diet-induced obesity and impaired glucose tolerance in rats following administration of leptin to their mothers. American Journal of Physiology: Regulatory Integrative Comprehensive Physiology 292 R1810-R1818. (doi:10.1152/ ajpregu.00676.2006)

Stoll-Becker S, Kreuder J, Reiss I, Etspüler J, Blum WF \& Gortner L 2003 Influence of gestational age and intrauterine growth on leptin concentrations in venous cord blood of human newborns. Klinische Padiatrie 215 3-8. (doi:10.1055/s-2003-36892)

Su PH, Wang SL, Chen JY, Lai CP \& Jian SH 2002 Serum leptin levels in preterm, healthy and sick-term newborns. Acta Paediatrica Taiwanica 43 249-254. (doi:10.3889/mjms.1857-5773.2012.0264)

Sugden MC, Langdown ML, Munns MJ \& Holness MJ 2001 Maternal glucocorticoid treatment modulates placental leptin and leptin receptor expression and materno-fetal leptin physiology during late pregnancy, and elicits hypertension associated with hyperleptinaemia in the early-growth-retarded adult offspring. European Journal of Endocrinology 145 529-539. (doi:10.1530/ eje.0.1450529)

Tanida M, Yamamoto N, Morgan DA, Kurata Y, Shibamoto T \& Rahmouni K 2015 Leptin receptor signaling in the hypothalamus regulates hepatic autonomic nerve activity via phosphatidylinositol 3-kinase and AMP-activated protein kinase. Journal of Neuroscience 35 474-484. (doi:10.1523/JNEUROSCI.1828-14.2015)

Toprak D, Gökalp AS, Hatun S, Zengin E, Arisoy AE \& Yumuk Z 2004 Serum leptin levels of premature and full-term newborns in early infancy: metabolic catch-up of premature babies. Turkish Journal of Pediatrics 46 232-238.

Valūniene M, Verkauskiene R, Boguszewski M, Dahlgren J, Lasiene D, Lasas L \& Wikland KA 2007 Leptin levels at birth and in early postnatal life in small- and appropriate-for-gestational-age infants. Medicina 43 784-791.

Varvarigou A, Mantzoros CS \& Beratis NG 1999 Cord blood leptin concentrations in relation to intrauterine growth. Clinical Endocrinology 50 177-183. (doi:10.1046/j.1365-2265.1999.00630.x) http://joe.endocrinology-journals.org

DOI: 10.1530/JOE-16-0273
() 2016 Society for Endocrinology Printed in Great Britain
Published by Bioscientifica Ltd. 
Vickers MH, Gluckman PD, Coveny AH, Hofman PL, Cutfield WS, Gertler A, Breier BH \& Harris M 2005 Neonatal leptin treatment reverses developmental programming. Endocrinology 146 4211-4216. (doi:10.1210/en.2005-0581)

Vickers MH, Gluckman PD, Coveny AH, Hofman PL, Cutfield WS, Gertler A, Breier BH \& Harris M 2008 The effect of neonatal leptin treatment on postnatal weight gain in male rats is dependent on maternal nutritional status during pregnancy. Endocrinology 149 1906-1913. (doi:10.1210/en.2007-0981)

Visentin S, Lapolla A, Londero AP, Cosma C, Dalfrà M, Camerin M, Faggian D, Plebani M \& Cosmi E 2014 Adiponectin levels are reduced while markers of systemic inflammation and aortic remodelling are increased in intrauterine growth restricted mother-child couple. BioMed Research International 2014401595. (doi:10.1155/2014/401595)

Ward AM, Moore VM, Steptoe A, Cockington RA, Robinson JS \& Phillips DI 2004 Size at birth and cardiovascular responses to psychological stressors: evidence for prenatal programming in women. Journal of Hypertension 22 2295-2301. (doi:10.1097/00004872-200412000-00011)

WHO 1995 Physical status: the use and interpretation of anthropometry. Report of a WHO Expert Committee. World Health Organization Technical Report Series 854 1-452.

Yildiz L, Avci B \& Ingeç M 2002 Umbilical cord and maternal blood leptin concentrations in intrauterine growth retardation. Clinical Chemistry and Laboratory Medicine 40 1114-1117. (doi:10.1515/cclm.2002.195)

Yokota I 2003 Roles of leptin and ghrelin during the perinatal period. Clinical Pediatric Endocrinology 12 57-65. (doi:10.1297/cpe.12.57)

Yura S, Sagawa N, Mise H, Mori T, Masuzaki H, Ogawa Y \& Nakao K 1998 A positive umbilical venous-arterial difference of leptin level and its rapid decline after birth. American Journal of Obstetrics and Gynecology 178 926-930. (doi:10.1016/S0002-9378(98)70525-3)

Yura S, Itoh H, Sagawa N, Yamamoto H, Masuzaki H, Nakao K, Kawamura M, Takemura M, Kakui K, Ogawa Y, et al. 2005 Role of premature leptin surge in obesity resulting from intrauterine undernutrition. Cell Metabolism 1 371-378. (doi:10.1016/j.cmet.2005.05.005)

Received in final form 12 August 2016

Accepted 8 September 2016

Accepted Preprint published online 9 September 2016 (c) 2016 Society for Endocrinology Printed in Great Britain
Published by Bioscientifica Ltd 